Vol. 1 | No. 4 | Oktober 2020 | Hal. 286 - 293

\title{
“APOTEK HIDUP” SEBAGAI UPAYA PENINGKATAN KESEHATAN MASYARAKAT DALAM MENCEGAH PENYEBARAN COVID-19
}

\author{
Abdul Hamid Aly ${ }^{*}$, Andry¹, Arif Zulfahmy1, Faisol Arifin1, Ima Kumalasari², Laras \\ Noviyanti', Mellyn Arinda Veranita1, Moch. Lucky Fahmi1, Noruddin'1, Widi Fitri \\ Anggraeni' ${ }^{1}$ Zahrok'u Syarofah' ${ }^{1}$ \\ ${ }^{1}$ Fakultas Ekonomi dan Bisnis, Universitas Islam Malang \\ ${ }^{2}$ Fakultas Ilmu Administrasi, Universitas Islam Malang \\ *Korespondensi email: abdulhamidaly@unisma.ac.id
}

\begin{abstract}
ABSTRAK
Tanaman Obat tidak hanya bermanfaat sebagai bahan rempah atau masakan tetapi melaui program apotek hidup dapat dimanfaatkan sebagai alternatif untuk menjaga dan merawat kesehatan secara alami tanpa adanya efek samping ditengah pandemic covid-19. Apotek hidup dilaksanakan di Dusun Klerek Desa Torongrejo berfokus pada RT 02 RW 01 dengan memanfaatkan potensi lahan daerah sekitar untuk menanam jahe, kunyit, kencur dan serai. Metode yang digunakan melalui sosialisasi edukasi kepada warga melalui door to door dan praktek pembuatan Apotek hidup. Hasil dari kegiatan KKN ini adalah: 1) tercipta kesadaran masyarakat tentang pentingnya Apotek Hidup ditengah Covid-19, 2) sosialisasi dan peningkatan pengetahuan masyarakat dalam mengolah lahan kosong untuk menjadi Apotek Hidup, 3) tahap pembuatan Apotek Hidup oleh mahasiswa bersama-sama dengan masyarakat, 4) lingkungan dapat menjadi lebih hijau, segar dan asri.
\end{abstract}

Kata Kunci: tanaman obat; apotek hidup; desa torongrejo.

\section{PENDAHULUAN}

Indonesia merupakan salah satu negara agraris dengan mayoritas penduduk bermata pencaharian sebagai petani dengan kegiatan bercocok tanam. Sebagai negara agraris Indonesia memiliki beragam sumber daya baik di daratan maupun di perairan. Faktor agraris inilah sehingga banyak berbagai macam tanaman yang dapat tumbuh di Indonesia. Tanaman tidak hanya bermanfaat sebagai bahan makanan ataupun sebagai hiasan. Tanaman juga banyak bermanfaat untuk penyembuhan dan pengobatan. Kemampuan tanaman toga dalam menyembuhkan dan memberikan efek positif dari beberapa tanaman sebagai obat telah lama diketahui secara turun menurun sebelum para ilmuwan menemukann berbagai obat-obatan dengan bahan kimia.

Dalam bidang tanaman obat, Indonesia dikenal sebagai salah satu negara yang memiliki keanekaragaman hayati terbesar kedua setelah Brazil, sehingga sangat potensial dalam mengembangkan tanaman obat. Indonesia kaya akan aneka ragam tanaman obat. Lebih dari 1000 spesies tumbuhan dapat dimanfaatkan sebagai bahan baku obat, oleh karena itu budidaya tanaman obat di Indonesia memiliki potensi yang sangat baik untuk dikembangkan. Pengembangan tanaman obat memiliki tingkat efektivitas yang cukup tinggi apabila dikelola dan dilaksanakan pada area Desa (Martino, Sulistyowati, \& Purnomo, 2018). Desa baik secara antropologi dan topografi memiliki tingkat lahan terbuka yang cukup tinggi dibandingkan dengan daerah perkotaan (Suparmini \& Wijayanti, 2015). 
“Apotek Hidup” Sebagai Upaya Peningkatan Kesehatan Masyarakat Dalam ...

Desa Torongrejo adalah sebuah desa yang berada di wilayah Kecamatan Junrejo, Kota Batu. Desa torongrejo memiliki luas wilayah $4.106 \mathrm{Km}$. Secara topografis Desa ini terletak pada ketinggian 700 meter di atas permukaan air laut. Desa Torongrejo yang terletak pada bagian selatan Kota Batu berbatasan langsung dengan, sebelah barat Kelurahan Temas, sebelah timur Desa Pendem Kecamatan Junrejo Kota Batu dan Desa Tawangargo Kecamatan Karangploso Kabupaten Malang, sebelah Utara Desa Pandarejo dan Desa Giripurno, serta sebelah selatan Desa Torongrejo dan Desa Mojorejo. Lahan di Desa sebagian besar merupakan Tanah Kering $36 \%$ dan Tanah sawah sebesar $64 \%$.

Mayoritas mata pencaharian penduduk Desa Torongrejo di bidang pertanian, baik dalam hal budidaya pertanian maupun perdagangan dari hasil pertanian. Sebagian lainnya adalah pegawai swasta, wirausahawan dan pegawai negeri sipil. Kondisi saat ini, masyarakat di Desa belum sepenuhnya memahami bahwa beberapa tanaman di sekitar mereka dapat digunakan sebagai obat yang dapat didistribusikan kepada industri obat-obatan, rumah sakit, maupun dapat dimanfaatkan untuk keperluan keluarga. Pengetahuan untuk memanfaatkan tumbuhan obat masih sebatas warisan budaya bangsa. Pengetahuan untuk memanfaatkan tanaman obat merupakan pengetahuan dan pengalaman yang diwariskan secara turun temurun (Oktora et al., 2006; Karamina, Supriyadi, Firman Yasin, Yusi Kamhar, \& Kusuma Astuti, 2020).

Obat tradisional adalah ramuan obat yang berasal dari tumbuh-tumbuhan yang berkhasiat (Parwata, 2016; Wadjdi et al., 2020). Menurut Jannah \& Primawati (2020) Tumbuhan atau tanaman obat tradisional merupakan tanaman yang dapat dipergunakan sebagai obat, baik yang disengaja ditanam (budidaya) maupun tanaman yang tumbuh secara liar Tanaman obat dapat dimanfaatkan sebagai dekorasi halaman maupun bahan ramuan alami untuk mengobati berbagi penyakit. Obat tradisional atau herbal biasanya dimanfaatkan oleh masyarakat menengah kebawah. Masyarakat biasanya memanfaatkan obat tradisional atau herbal untuk mencegah, menyembuhkan, memulihkan, serta meningkatkan Kesehatan (Harbie, 2015). Menurut Ningsih (2016) beralihnya masyarakat kepada obat tradisional karena harga lebih murah, bahan lebih mudah didapatkan bila ditanam sendiri, dan umumnya satu tanaman memiliki efek farmakologi lebih dari satu sehingga bermanfaat untuk pengobatan penyakit degeneratif dan metabolik.

Apotek hidup pada dasarnya merupakan pemanfaatan sebidang tanah kosong baik dihalaman rumah, ladang ataupun kebun yang digunakan untuk membudidayakan tanaman yang berkhasiat sebagai obat. Dalam upaya pelayanan kesehatan, ketersediaan obat dalam jenis yang lengkap, jumlah yang cukup, terjamin khasiatnya, dengan biaya yang murah merupakan permasalahan yang sulit dipecahkan. Undang-undang No. 23 tahun 1992 tentang kesehatan disebutkan bahwa obat tradisional adalah bahan atau ramuan berupa tumbuhan yang secara turun temurun telah digunakan untuk pengobatan berdasarkan pengalaman.

Program Apotek hidup memiliki beberapa manfaat bagi lingkungan salah satunya adalah lingkungan dengan apotek hidup akan cenderung lebih asri, tenang, dan hijau. Oksigen yang dihasilkan dari tanaman di apotek hidup akan membuat udara di sekitar lingkungan menjadi lebih bersih dan segar. Manfaat yang lain untuk kebaikan tubuh warga adalah dengan melakukan sebuah aktivitas sehari-hari yang positif. Aktivitas merawat apotek hidup misalnya, dengan memberi pupuk tanaman secara teratur, menyirami tanaman setiap pagi, menyabut rumput liar yang tumbuh di sekitar tanaman, akan menjadikan tubuh untuk melakukan pergerakan sehingga tubuh akan menjadi lebih bugar.

Pengertian apotek hidup adalah memanfaatkan sebagian tanah untuk ditanami tanaman obat-obatan untuk keperluan sehari-hari. Apotik hidup merupakan istilah penggunaan lahan yang ditanami tumbuhan yang berkhasiat untuk obat secara tradisional (Syarif, Suryotomo, \& Soeprapto, 2011; Wisnubrata, 2020). Umum diketahui, bahwa banyak 
obat-obatan tradisional yang dapat digunakan untuk mengobati berbagai penyakit. Obat tradisional umumnya lebih aman karena bersifat alami dan memiliki efek samping yang lebih sedikit dibandingkan obat-obat buatan pabrik. World Health Organization (WHO) merekomendasi penggunaan obat tradisional termasuk obat herbal dalam pemeliharaan kesehatan masyarakat, pencegahan dan pengobatan penyakit, terutama untuk kronis, penyakit degeneratif dan kanker (Setiawati, Immanuel, \& Utami, 2016). Menurut Aseptianova dalam Rahmawati (2019) "Semua jenis tanaman obat memang mengandung senyawa kimia alami, yang memiliki efek farmakologis dan aktivitas penting sampai berpotensi sebagai agen anti penyakit degeneratif". Itulah sebabnya sebagian orang lebih senang mengkonsumsi obat-obat tradisional daripada mengkonsumsi obat dokter. Apotek hidup mempunyai berbagai manfaat, antara lain:

1. Aman bagi kesehatan karena yang digunakan merupakan tanaman yang alami.

2. Lebih menghemat biaya hidup karena tanaman yang digunakan dapat dipakai untuk membuat obat atau digunakan berbagai produk sehari-hari dengan cara yang mudah.

3. Dapat dibuat menjadi obat herbal yang lebih bermanfaat dan lebih banyak khasiatnya.

4. Membuatorang yang memilikinya pintar dalam hal pemanfaatan tanaman terutama tanaman obat.

5. Dengan memiliki apotek hidup, rumah menjadi asri, cantik, sehat.

6. Tanaman dapat memberikan efek psikologis bagi orang yang sedang sakit sehingga lebih cepat sembuh.

Merawat tanaman juga menjadi sarana Anda menggerakkan tubuh dan berolahraga. Hasilnya tubuh menjadi sehat dan cantik.

Dari uraian tersebut, maka tujuan dari pengabdian ini adalah untuk memberi pengetahuan mengenai manfaat tanaman obat tradisional sebagai alternative pengobatan dan langkah antisipatif dalam menjaga dan merawat kesehatan secara alami di tengah pandemi Covid-19, serta untuk mengurangi pengeluaran perekonomian keluarga terhadap pembelian obat-obatan kimia yang cenderung mahal. Selain itu pengabdian ini juga bertujuan sebagai upaya meningkatkan kesehatan masyarakat melalui apotek hidup yang besinergi dengan Program RT Siaga KKN Kelompok 64.

\section{METODE}

Pengabdian ini dilaksanakan pada bulan Agustus 2020 selama 1 bulan yang bertempat di Desa Torongrejo, khusunya dusun Klerek RT 06 RW 04. Pengabdian ini dilakukan oleh mahasiswa KKN Tematik Edisi Covid-19 Kelompok 64 Tahun Akademik 2017/2018, berkolaborasi dengan dosen pembimbing Lapangan. Metode pengabdian yang digunakan yaitu dengan melakukan sosialisasi kepada warga terlebih dahulu, selanjutnya masuk ke tahap pembuatan apotek hidup.

Tabel 1. Rincian metode pengabdian

\begin{tabular}{|c|c|c|c|c|}
\hline No & $\begin{array}{c}\text { Metode } \\
\text { Pengabdian }\end{array}$ & Kegiatan & Tujuan & Output \\
\hline 1 & $\begin{array}{l}\text { Sosialisasi manfaat } \\
\text { dan pembuatan } \\
\text { apotek hidup }\end{array}$ & $\begin{array}{l}\text { Menyelenggarakan sosialisasi } \\
\text { mengenai manfaat yang bisa } \\
\text { didapatkan dari pengelolaan } \\
\text { apotek hidup dan } \\
\text { menjelaskan langkah-langkah } \\
\text { pembuatan apotek hidup di } \\
\text { Desa Torongrejo RT } 06 \text { RW } 04\end{array}$ & $\begin{array}{l}\text { Tujuan dari kegiatan } \\
\text { pembuatan apotik hidup } \\
\text { adalah agar masyarakat } \\
\text { lebih mandiri sehingga } \\
\text { ketika sakit, tanaman } \\
\text { apotik hidup dapat } \\
\text { langsung dijadikan obat }\end{array}$ & $\begin{array}{l}\text { a. Diharapkan masyarakat } \\
\text { Peduli terhadap tanaman } \\
\text { yang berguna untuk } \\
\text { kesehatan } \\
\text { b. Diharapkan masyarakat } \\
\text { paham dalam memanfaatkan } \\
\text { apotik hidup bagi kesehatan }\end{array}$ \\
\hline 2 & $\begin{array}{l}\text { Pembuatan } \\
\text { Apotek Hidup }\end{array}$ & $\begin{array}{l}\text { Melakukan Pencarian bibit, } \\
\text { pembuatan dan penanaman } \\
\text { apotek hidup bersama warga } \\
\text { RT } 06 \text { RW } 04\end{array}$ & & $\begin{array}{l}\text { Menciptakan inovasi baru } \\
\text { untuk membudidayakan } \\
\text { apotek hidup sebagai } \\
\text { penunjang ekonomi } \\
\text { masyarakat }\end{array}$ \\
\hline
\end{tabular}




\section{HASIL DAN PEMBAHASAN}

Sosialisasi mengenai pemanfaatan dan pembuatan apotek hidup dilakukan di lingkungan RT 06. Adapun rincian dari kegiatan tersebut dapat dijelaskan sebagai berikut:

\section{Sosialisasi Manfaat dan Pembuatan Apotek Hidup}

Apotek hidup adalah lahan tanah yang dimanfaatkan sebagai tempat menanam berbagai jenis tanaman yang memiliki banyak khasiat, baik tanaman obat maupun tanaman sayur sayuran. Sosialisasi mengenai manfaat dan cara pembuatan apotek hidup dilakukan di rumah-rumah warga RT 06. Sosialisasi mengenai manfaat dan cara pembuatan apotek hidup pertama kali dilakukan di lingkup RT 06 pada tanggal 03 agustus 2020, persiapannya dimulai satu hari sebelum hari H. Persiapan yang dilakukan berupa pembuatan dan penyebaran undangan, penyiapan materi untuk melakukan sosialisasi. Pada acara sosialisasi ini menjelaskan beberapa contoh tanaman yang bisa ditanam di dalam apotek hidup dan bibit tanaman yang mudah ditemui selain itu juga kami menjelaskan pula manfaat dari apotek hidup itu sendiri.

Adapun beberapa pertanyaan yang muncul terkait tentang pengembangan apotek hidup karena jarangnya apotek hidup yang dapat ditemui di lingkungan sekitar rumah warga, Ketua RT 06 Bapak Muliono memaparkan bahwa lingkungan sekitar rumah warga tengah dilakukan program serentak penanaman sayur guna menjaga ketahanan pangan warga RT 06. Beliau turut menambahkan bahwa program Apotek hidup yang dilaksanakan oleh Mahasiswa KKN Kelompok 64 Unisma ini sangatlah bermanfaat bagi warga RT 06.

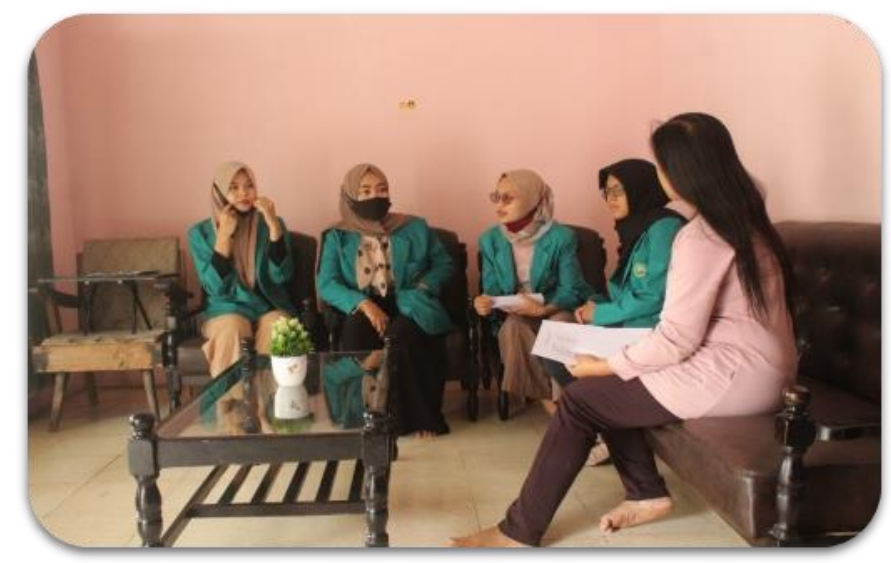

Gambar 1. sosialisasi door to door yang dilakukan kerumah warga RT 06

Diperlukan rentang waktu selama 1 minggu (7 hari) untuk melaksanakan sosialisasi ke warga RT 06 RW 04 melalui rumah ke rumah hal tersebut dilakukan karena tidak diperkenankannya melakukan kegiatan yang bersifat mengumpulkan beberapa jumlah orang dalam sekali waktu. Pemerintah Desa Torongrejo cukup kooperatif dalam memberikan informasi dan memfasilitasi mahasiswa KKN terutama dalam memberikan surat pemberitahuan resmi kepada masyarakat RT 06 RW 04.

Kegiatan sosialisasi berlangsung lama karena dalam RT yang difokuskan terdiri atas 41 Kepala Keluarga atau 41 Rumah yang harus didatangi, dengan jumlah perhari sebanyak 7-8 rumah yang harus dilakukan pendalaman sosialisasi guna mendapatkan efektifitas program dan mengoptimalkan daya dukung masyarakat RT terhadap program yang telah disusun oleh Kelompok KKN 64 Universitas Islam Malang. 


\section{Pembuatan Apotek Hidup}

Persiapan untuk membuat apotek hidup kami mulai dari tanggal 03 agustus 2020, dimulai dari tahapam survey lokasi yang akan digunakan sebagai tempat pengembangan bibit, kemudian dilanjutkan dengan survey tempat pembelian bibit tanaman yang akan ditanam. Terlebih dahulu kami pilih-pilih terlebih dahulu jenis tanaman yang akan ditanam. Tahapan selanjutnya adalah membeli pupuk dan peralatan yang akan digunakan untuk proses perawatan apotek hidup.

Kegiatan pembuatan tanaman ini dimulai dari jam 09.00 WIB-12.00 WIB. Kegiatan ini dimulai dari penanaman bibit setelah mempersiapkan peralatan dan bahan. Media yang digunakan adalah penggunaan Polybag kecil beserta pupuk yang telah tercampur dengan tanah. Penggunaan polybag merupakan alternative ketersediaan tempat agar lebih mudah dalam hal pemantauan, penyiraman dan perawatan bibit.

Tahapan selanjutnya adalah melakukan penanaman bibit dan pemberian label stiker yang telah disiapkan oleh mahasiswa KKN 64 Unisma, Pemberian label tersebut guna untuk membedakan jenis tanaman yang telah ditanam. Selanjutnya Mahasiswa KKN Unisma melakukan perawatan bibit dan maintenance program selama kurang lebih 2 minggu dari awal penanaman bibit.

Gambaran kerja proses pembuatan apotek hidup dan aktivitas mahasiswa KKN Kelompok 64 Universitas Islam Malang. Terlihat pada gambar 2-6.

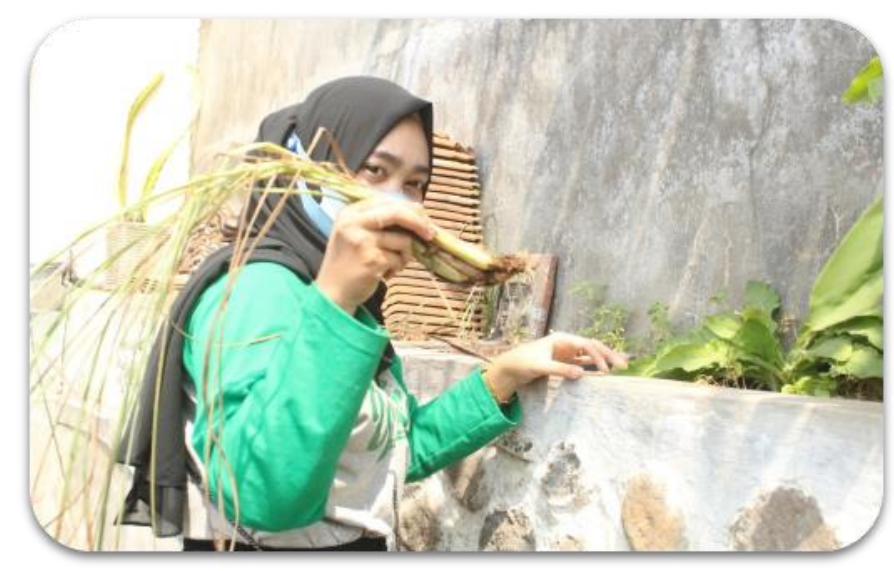

Gambar 2. Pencarian Bibit Program Apotek Hidup

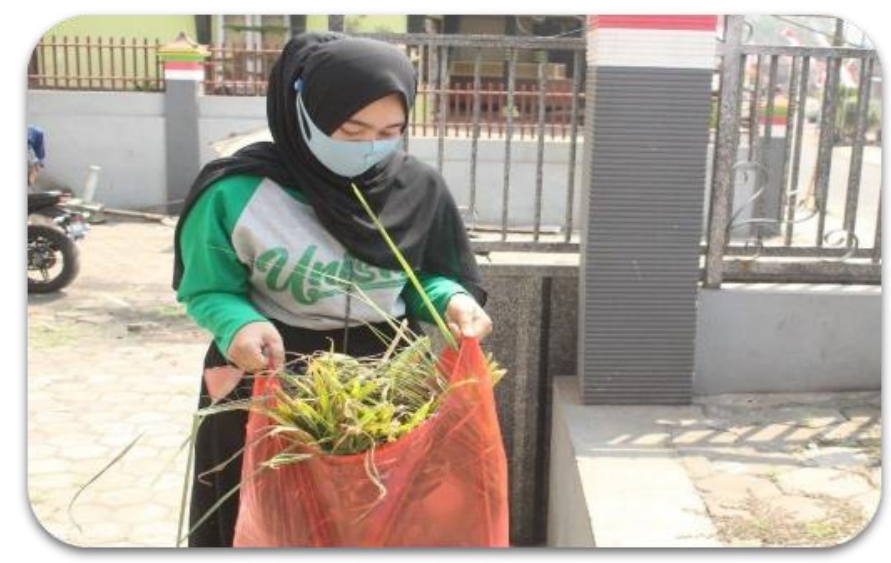

Gambar 3. Pembelian bibit 


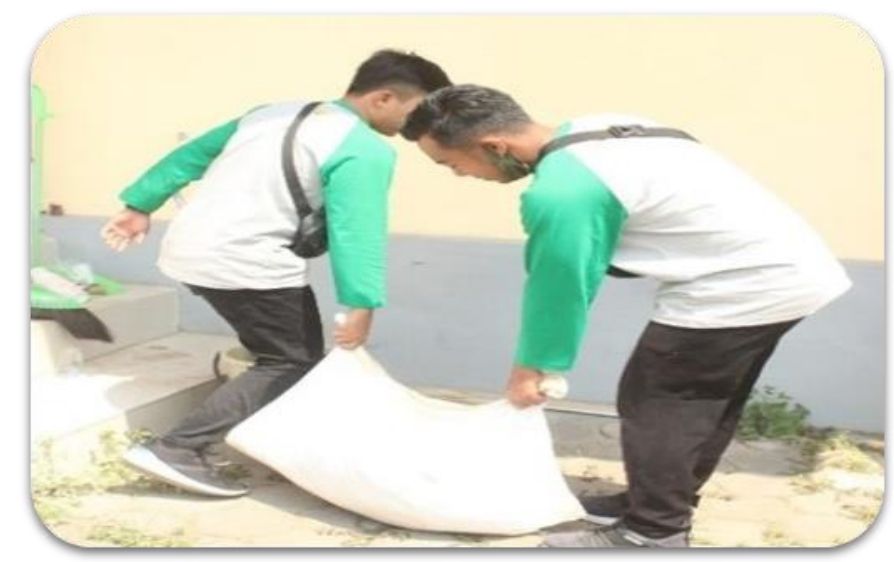

Gambar 4. Persiapan Bahan baku pupuk dan peralatan penunjang

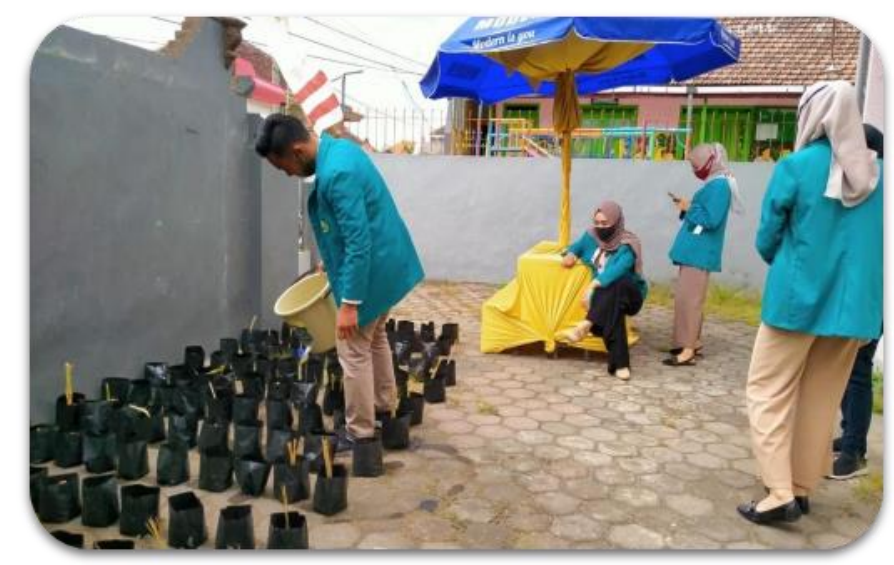

Gambar 5. Penyiraman dan Perawatan Bibit

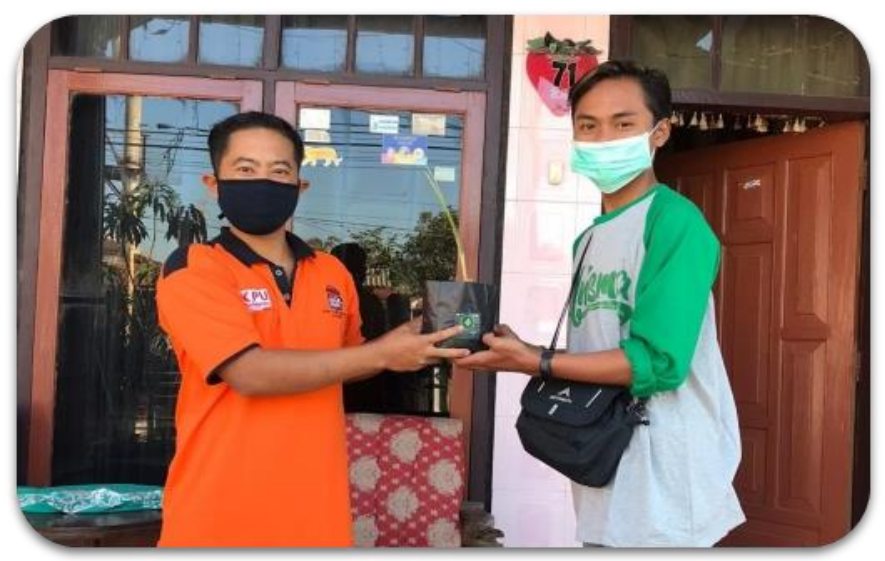

Gambar 6. Penyerahan Tanaman Apotek Hidup kepada Warga RT 06 RW 04

Hasil nyata yang didapatkan dari program penanaman tanaman obat keluarga (Apotek Hidup) ini adalah masyarakat RT 06 RW 04 Desa Torongrejo, mampu mengetahui manfaat penggunaan tanaman obat keluarga lebih optimal. Selain itu, masyarakat Desa Torongrejo juga mengetahui nilai ekonomis dan tingkat aman dari kegunaan tanaman obat keluarga. Masyarakat juga dapat mengkonsumsi tanaman ini sebagai alternative pengobatan herbal selama masa pandemic Covid-19. Disisi lain hadirnya apotek hidup juga memberikan fakta dan pengetahuan dari bidang keilmuan yang lebih ilmiah dibandingkan dengan pengetahuan yang bersifat turun- menurun. 


\section{KESIMPULAN}

Program apotek hidup sangat bermanfaat bagi masyarakat Indonesia khususnya Dusun Klerek Desa Torongrejo. Mengingat Indonesia adalah salah satu negara agraris, dengan membudidayakan tanaman obat keluarga (apotek hidup) sama saja dengan melestarikan kearifan yang dimiliki oleh Indonesia. Dengan melestarikan pembudidayaan tanaman obat di Dusun Klerek ini juga dapat membuat pekarangan rumah masyarakat menjadi lebih bermanfaat, masyarakat juga secara tidak langsung melakukan penghematan dalam bidang ekonomi serta dalam menghindari efek jangka panjang pengkonsumsian obatobatan kimia.

Dari kegiatan-kegiatan tersebut dampak yang didapatkan yakni warga Desa Torongrejo mendapatkan pengetahuan bagaimana memanfaatkan lahan yang ada menjadi apotek hidup yang memiliki banyak sekali manfaat. Dari hasil sosialisasi yang diselenggarakan melalui rumah ke rumah, warga Desa torongrejo dapat mempraktikkan sendiri apa yang telah disampaikan dan dipelajari di kemudian hari.

\section{DAFTAR RUJUKAN}

Aseptianova. (2019). Pemanfaatan Tanaman Obat Keluarga Untuk Pengobatan Keluarga Di Kelurahan Kebun Bunga Kecamatan Sukarami-Kota Palembang. Batoboh Jurnal Pengabdian Pada Masyarakat, 4(1), 1-25. https://doi.org/10.26887/bt.v3i1.680

Harbie, T. (2015). kitab Tanaman Berkhasiat Obat 226 Tumbuhan Obat untuk Penyembuhan Penyakit dan Kebugaran Tubuh. Yogyakarta: Octopus.

Jannah, H., \& Primawati, S. N. (2020). Identifikasi Tanaman Obat Untuk Menunjang Kesehatan Anak Usia Dini. Bioscientist. Jurnal Ilmiah Biologi, 8(1), 32-38. https://doi.org/10.33394/bjib.v8i1.2687

Karamina, H., Supriyadi, S., Firman Yasin, D. D., Yusi Kamhar, M., \& Kusuma Astuti, F. (2020). Pemanfaatan dan Penanaman Tanaman Obat Keluarga (TOGA) Menuju Keluarga Sehat Pada Ibu Pemberdayaan Kesejahteraan Keluarga (PKK). Jurnal Inovasi Hasil $\begin{array}{lll}\text { Pengabdian } \quad \text { Masyarakat } & \text { (JIPEMAS), }\end{array}$ https://doi.org/10.33474/jipemas.v3i2.6416

Martino, Y. A., Sulistyowati, E., \& Purnomo, Y. (2018). Model Pemberdayaan Santri Ponpes Al-Hidayah Batu Malang Sebagai Kader Kesehatan Berbasis Terapi Herbal. Jurnal Inovasi Hasil Pengabdian Masyarakat (JIPEMAS), 1(2), 86-93. https://doi.org/10.33474/jipemas.v1i2.1514

Ningsih, I. Y. (2016). Studi Etnofarmasi Penggunaan Tumbuhan Obat Oleh Suku Tengger Di Kabupaten Lumajang Dan Malang, Jawa Timur. Pharmachy, 13(1), 10-20. Retrieved from http://jurnalnasional.ump.ac.id/index.php/PHARMACY/article/view/885

Oktora, L., Kumala, R., Staf, S., Program, P., Farmasi, S., \& Pendahuluan, U. J. (2006). Pemanfaatan Obat Tradisional Dengan Pertimbangan Manfaat Dan Keamanannya. Majalah Ilmu Kefarmasian, 3(1), 1-7. https://doi.org/10.7454/psr.v3i1.3394

Parwata, I. M. O. A. (2016). Obat Tradisional. Denpasar.

Setiawati, A., Immanuel, H., \& Utami, M. T. (2016). The inhibition of Typhonium flagelliforme Lodd. Blume leaf extract on COX-2 expression of WiDr colon cancer cells. Asian Pacific Journal of Tropical Biomedicine, 6(3), 251-255. https://doi.org/10.1016/j.apjtb.2015.12.012

Suparmini, \& Wijayanti, A. T. (2015). Masyarakat Desa dan Kota (Tinjauan Geografis, Sosiologis, dan Historis). Buku Ajar. Yogyakarta: UNY Press.

Syarif, P., Suryotomo, B., \& Soeprapto, H. (2011). Diskripsi dan Manfaat Tanaman Obat di Pedesaan Sebagai Upaya Pemberdayaan Apotik Hidup (Studi Kasus di Kecamatan Wonokerto). PENA: Jurnal Ilmu Pengetahuan Dan Teknologi, 21(1), 20-32. 
https://doi.org/10.31941/jurnalpena.v21i1.49

Wadjdi, M. F., Cahyaning Thias, T. A., Qatrunnada, L., Asga, I. D., Ni'mah, M., Makruf, A., ... Choiruddin, A. (2020). Pengembangan Jamu Olahan Rumah Tangga Untuk Meningkatkan Perekonomian Masyarakat Melalui Pemasaran E-Commerce. Jurnal Pembelajaran Pemberdayaan Masyarakat (JP2M), 1(2), 143-147. https://doi.org/10.33474/jp2m.v1i2.6506

Wisnubrata. (2020). Mengenal Apotek Hidup dan Berbagai Jenis Tanaman Obatnya. Kompas.Com.

Retrieved from https://lifestyle.kompas.com/read/2020/05/20/170437020/mengenal-apotekhidup-dan-berbagai-jenis-tanaman-obatnya?page=all 